\title{
Some interfaces in conventional and distance education programmes in a postmodern context
}

\author{
F. R. Aluko \\ Faculty of Education \\ Department of Curriculum Studies \\ University of Pretoria \\ South Africa \\ e-mail: alukoruth@yahoo.com \\ W. J. Fraser \\ Faculty of Education \\ Department of Curriculum Studies \\ University of Pretoria \\ South Africa \\ e-mail:william.fraser@up.ac.za
}

\section{J. Hendrikz}

Distance Education Unit

University of Pretoria

South Africa

e-mail: johan.hendrikz@up.ac.za

\begin{abstract}
This article emanates from a comparative study of the quality of a B.Ed. (Hons) programme in contact and distance contexts in a dual-mode institution, in terms of access, delivery and output. Both versions of the programme are guided by a similar underpinning philosophy that drives its ethos. Even though it appears that there may be no prominent discrepancies between the two modes of training delivery, institutions that decide to venture into rural areas are faced with challenges that have to be sorted out if the quality of a given distance education programme is to be enhanced. Also, there is the need for institutions to distinguish between academe that are interested in distance education and those that are not in order to improve on their research status. Finally, suggestions are proffered on how institutions in an African setting can improve the quality of their programmes.
\end{abstract}

\section{INTRODUCTION}

Despite the long history enjoyed by distance education ${ }^{1}$ and the enhancement of its reputation recently, it is ironical that there is still some persistence in regarding it as the second-best option (Braimoh 2003). Even in countries where distance education 
has for many years been an available option, there still exists the belief (among academics in particular) that conventional education is 'real' education. Therefore, any non-traditional education is allowed to act on a complementary, somehow subordinate basis (Tsolakidis 2000). Evidence abounds in literature that the singular reason for this is mainly 'quality' (Du Plessis and Van Der Merwe 2005).

Consequently, most research on distance education focuses on comparative studies of distance and traditional methods of education (Russell 1999). Though it has been thought that there may no longer be the need for such comparative studies, the evidence of this is inconclusive (Makin 2001). Also, it is the researchers' view that ending of further research in this particular area, especially in third world countries such as South Africa, would be a paradox; this is because this mode of delivery appears as at now to be the saving grace of all African countries.

However, it is not the researchers' interest to focus on 'Which method is better?' (Diaz 2000), but the focus would rather be on what discrepancies may exist in distance education, which have resulted in the prevailing skepticism, and to focus on suggestions for alleviating such skepticism. Consequently, it is the focus of this work to compare conventional and distance education in terms of Access, Delivery Mode and Output. The aim is to fill the gaps already identified in past comparative studies which include among others (Lockee, Moore and Burton 2001):

- Failure to adequately define and differentiate between the two forms of education;

- Lack of taking into consideration other factors that affect the failure or success of students;

- Lack of focus on the total academic programme; and

- Inadequate reasons for higher dropout rates of distance education students.

Therefore, the research question that was posed for the study was: What is the impact of distance and conventional education on the performances of learners in a postgraduate B.Ed. (Hons) degree programme with specialisation in Education Management, Law and Policy, when assessed in terms of access, delivery mode and output?

\section{ASSESSMENT OF THE QUALITY OF BOTH CONTACT AND DISTANCE EDUCATION PROGRAMMES}

Distance education is in many ways a welcome phenomenon, even though it creates challenges for and arouses concern among many in the higher education community. It holds enormous promise for enriching education and to focus on its negative aspects only would be a distortion (Eaton 2001). For instance, in Nigeria less than 10 per cent of qualified prospective students could gain admission to conventional tertiary institutions (Umar 2006). Distance education is therefore absolutely essential if the remaining $90+$ per cent were to be allowed access to higher education. 
According to Bloland (1995), postmodernism makes us aware of the destabilisation and uncertainty that we confront not only in society, but also in higher education. Of relevance here are the interfaces among the three indices of assessment raised in this study. Also, several questions have to be answered. For instance, what is the quality of the access given to students as well as of the delivery modes, and what are the genuine reasons for students' low output? This brings into focus the question of quality that has been raised in higher education in general, but in distance education in particular (Aluko 2007).

\section{The notion of quality ${ }^{2}$}

Review of literature (Bornman 2004) reveals that there is no consensus among many on the definition of 'quality' in terms of education. In fact, past attempts have shown that the term could prove illusory, difficult and elusive (Sahney, Banwet and Karunes 2004). A major reason for this is because constructions of quality are socially indexed - they change over time, and vary according to political and cultural context (Welch 2000).

Green (1994, 15-16), identifies the following as definitions that have been adopted by users in higher education: quality as fitness for purpose; as effectiveness in achieving institutional goals; and as meeting customer's stated or implied needs. Also, a literature survey indicates that the majority of authors define quality as continuously meeting and exceeding the needs of customers (Steyn 2000, 9). Having perused available literature on the concept, the researcher is also of the opinion that each scholar should try and come up with a framework of what quality should mean, based on the purpose of the study (Bornman 2004).

\section{Quality of the access given to students to attend the B.Ed. (Hons) programme and the university}

The term access can generally be assumed to mean opening opportunities for people who were once excluded so as to attend college (Herman and Mandell 1999) in order to give them a second chance (Holmberg 2001). Nevertheless, Cele and Brandt (2005), identify various forms of access to teaching and learning which include 'access to space; access to resources; access to knowledge [termed epistemological access by Jansen (2001)]; access to skills and competency; access to dialogue; access to workplace education and access to feedback'.

The question of access to higher education has become a powerful policy objective throughout the Commonwealth because it is linked to economic rationales and those of democratisation and social inclusion (Morley, Unterhalter and Gold 2003). For example, in South Africa the government sees distance education as a means of equalising tertiary education access for the majority who have been denied (Department of Education 2001). Thus, conventional education institutions in South Africa have been addressing themselves to admission strategies that widen access to higher education and facilitate the academic development of students 
from disadvantaged educational backgrounds (Council on Higher Education 2004). Hence, the advice is that institutions irrespective of the modes, should put in place proper structures, and should continually evaluate non-instructional areas such as registration, advise library and media resources, and provide technical support (Cele and Brandt 2005).

Also, there are many implications for widening access, which often lead to the paradox of invitation and exclusion (Herman and Mandell 1999). For instance, the ratio of educator to students often increases immensely without a corresponding increase in the necessary finances (Singh 2001). Additionally, Scott (2003) identifies a chronic tension between widening participation on the one hand and quality and standards on the other, which has continuously been a key developmental dilemma. Furthermore, there is the problem of technology, which polarises the technological haves and have-nots, and the wired world from those without access to it (Hellman 2003). Ironically at present, access to ICT can be met by very few African countries (Lelliot, Pendlebury and Enslin 2000).

Another burning issue is that of the student loan scheme, which has received much criticism based on the fact that students are indebted before they find employment, even when such employment is not assured. Hence, the question: 'Who pays for the cost of opening up access?'

\section{Quality of the learning experiences of students in both modes of delivery}

Gone are the days when time, location and place of study were the measuring indicators for quality of education (Ragan 1999). However, there is a need to ensure the quality of the education provided irrespective of the form. Previously in South Africa, both the conventional and traditional distance institutions delivered instruction mainly through face-to-face contact, largely depending on print as a mode of delivery (Burke 2002).

In spite of its shortcomings, there is a continued general romance with print as it is inexpensive to develop; its context is now improved in terms of better prepared texts, high quality material development processes, and enhanced desktop development practices (Garrison and Archer 2000; Adekanmbi 2004). This is due to the shift from a teacher-centered instruction or teaching paradigm to a studentcentred 'learning paradigm', which creates environments and allows for experiences that encourage self-discovery and construction of knowledge (Fraser and Lombard 2002). Nevertheless, this has to go hand-in-hand with some principles for educational practice proposed by Chickering and Gamson 1991, 5), which are

- Encouragement of student-faculty contact

- Co-operation among students

- Encouragement of active learning

- Prompt feedback 
- Emphasising time-management on task

- Communicating high expectations and

- Respect of diverse talents and ways of learning.

\section{Possible factors influencing students' output}

Past studies (Dhanarajan 2001) have revealed that the delivery mode of a form of education and its quality are directly related to access (either positively or negatively) and to the throughput rates. An important element in output, in relation to quality, is the performance of students or achievement of students which should also extend to include the non-completion rate of students as many drop out of the educational system before they complete their courses. Citing various research findings, Yorke (1999) groups reasons for student non-completion of courses as the following: course factors, institutional factors, study environmental factors, personal blame and motivational factors.

In South Africa it is an established fact that there is high attrition rate in higher education (Department of Education 2004). However, this is not peculiar to the country. In fact, it is a popular phenomenon in countries that have refocused their higher education from elitism to mass opportunity (Mckenzie and Schweitzer 2001).

\section{RESEARCH METHODS AND SAMPLE}

Given the gaps already identified in past comparative research (mostly quantitative in nature), the mixed-methods research approach was applied here in order to gain a holistic picture of the interfaces between the three indices in relation to quality. The unit of study for the research was the Education Management, Law and Policy programme from a Faculty of Education at a local university, which took place concurrently in both a conventional education and a distance education context. The research started in 2005, and data were collected using one-on-one semi-structured and focus group interviews, telephone interviews, questionnaires (containing both open-ended and closed questions), as well as micro and macro documents in order to obtain qualitative and quantitative data. The researchers made use of purposive sampling, while all the instruments were piloted on a sample of the proposed participants. The participants included 127 distance education students, 45 conventional education students, six module coordinators, ten course presenters, four tutors, four administrators and one instructional designer. Finally, ten students from both modes that had discontinued their studies also participated in the investigation.

\section{ANALYSIS OF BOTH QUALITATIVE AND QUANTITATIVE DATA}

The quantitative data collected were analysed through the use of descriptive and inferential statistics, and tabulation. However, responses to the questionnaire were 
coded manually as the number of respondents was relatively small, and the completed copies of the questionnaire were later taken to the statistician for computer analysis. Non-parametric tests - the chi-square and Fisher's exact tests were combined (Cohen, Manion and Morrison 2000) in order to ascertain the reliability of the exact probabilities, as well as to strengthen the evidence of the statistically significant relationships between the two groups (Steyn, Smit, Du Toit and Strashem 1994). Also, the Phi coefficient was used to test for the practical significance (effect size) of the rates compared ( $w=0.1$ small effect; 0.3 medium effect; 0.5 large effect). The level of significance was therefore described as $p<0.05$. The aim was to analyse the 'Phi coefficient used for the analysis of the relationship between two dichotomous variables' (Bryman 2004, 235). The effect sizes as applied to the statistical analysis indicated whether the relationship between the pass and the failure rates of the two student groups under investigation was weak, moderate or strong.

Furthermore, due to the fairly large number of interviewees, 'computer assisted qualitative data analysis software' (CAQDAS) (Atlas's 5.0) was employed to analyse the transcribed interviews due to the fairly large number of the interviewees. Also, relevant quotations were identified and codes based on the concepts and themes frequently mentioned by interviewees (Hardy and Bryman 2004).

\section{MAIN FINDINGS FROM BOTH QUANTITATIVE AND QUALITATIVE INVESTIGATIONS AND DISCUSSION}

\section{Quality of the access given to students on the programme}

Findings from this study revealed that due to government's policy on opening up access (Department of Education 2001), the B.Ed. (Hons.) Education Management, Law and Policy programme (a postgraduate course) was identified as one of the niche areas to develop and aid in meeting this need. It targeted certain geographical areas of South Africa that were not well served by other universities. Thus, students on the program were predominantly female blacks, who chose the institution based on its quality reputation. This becomes important because the university was previously a university for Afrikaans-speaking South Africans. Altogether, 36 students (22.5\%) were university graduates with the first degree, while 124 students $(77.5 \%)$ were non-graduates who possessed Diplomas and Advanced Certificates in Education.

However, due to the fact that the university diversified into rural areas, it had to limit its choice of technology - in this case print - to provide equal access to students coming into the programme (Bates 2005). Although these students could identify with the choice of media, there still existed some gaps, which Hellman (2003) referred to as the digital divide. Ironically, many module coordinators and course presenters were of the opinion there was a difference between the performances of students from the two delivery modes who had access to other technologies, from those who did not. This supports earlier warnings on exclusion and inclusion, and the quality of access given to students (Smith and Webster 1997; Morrow 1993/4; Game 2005). 
Unfortunately, it was revealed that only students from conventional education had access to non-instructional support, such as counseling, while the majority of distance education students responded negatively to the questions concerning the availability of these services. Therefore, most distance education students identified areas of need for counseling, which included career counseling, studying, time management, and how to write examinations and complete assignments - these are already identified areas of challenges for students in DE (Mostert 2006; Raphael 2006). For instance, distance students were expected to phone in to the university, which meant additional expenses (a cost some of them complained about). Subsequently, they rarely phoned in for academic advice. Unfortunately, as Gelderbloem (1996) laments, most of the needed initiatives are expensive. Nevertheless, we think that introducing call-centers with toll-free lines would go a long way to alleviate this major problem.

Also, majority of the students that participated in this study indicated they struggled financially, which forced them to make use of the loan scheme available at the university (Aluko 2007). Similarly, this supports the assertion made earlier by Pityana (2006), namely: that one of the consequences of low funding "is that students' fees have increased in order to match the funding shortage". As expected, responses of students to the questionnaire indicated complaints about high study fees, and the picture on the international scene is not entirely different (USA Funds 2007). This, among other factors, often signals the lower probability of students completing their studies, and low motivation to study (Qurashi, Morton and Antosz 2002).

According to Scott (2003), there must be a way to ensure increasing access to education for all people without losing credibility in the face of financial stinginess on the part of government. Though the financial budget of the South African government for 2007 reflects that the lion's share has been allocated for education purposes, and, according to the Finance Minister (South Africa Information 2007), R700 million of this budget has been set aside for bursaries to encourage young people to train as teachers little or nothing has been mentioned about the possible impact of these on Distance Education.

\section{The quality of students' learning experiences in relation to delivery and output}

Though orientation, which the institution did through tutorial letters for distance education students is necessary to familiarise students with and prepare them for the study field (Raphael 2006), nevertheless, many interviewees complained that distance students sometimes never opened their learning materials before arriving for contact sessions, which could suggest that they had little or no knowledge about the expectations of the programme. Thus, Tresman (2002) suggests that universities should introduce pre-orientation courses which the researchers agree should be more creative. Conversely, the researchers concur with Telford and Masson (2005) that unless students also play their expected roles within the educational system, it will 
be difficult to realise the goals of a programme, no matter the efforts of the institution concerned.

One of the areas of complaints was the lack of interactivity of some learning materials, and, a way of dealing with this is to discover the learning styles and learning preferences of students, and to take these into consideration when designing the learning materials (Goold and Rimmer 2000). Also, individual differences should be of particular interest to providers of distance education because there is usually no teacher readily available to explain, adapt or tailor the materials to an individual's need as and when it arises (Logan and Thomas 2002). Another possible source of assistance for universities on this matter could be collaboration among universities with similar teaching programmes, for the purpose of managing production cost and improving the quality of such materials (Rockwell, Furgason and Marx 2000; Council on Higher Education 2004).

Of relevance are the organisational issues, among which are the administrative structures that Lambert and Williams (1999) regard as critical to the long-term success of any given programme. Though students rated the administrative services at the faculty as good, they felt there were areas that needed serious attention. An example was the late delivery of tutorial packages and other necessary information to distance education students due to delays in the postal delivery system, (which the staff obviously viewed as beyond their control). The study also highlighted the need for the provision of adequate staffing and the appointment of specific staff to specific roles, for instance to efficiently attend to the 20,000 calls per month received by the office.

Part of what defines a quality learning experience is the support structure that an institution has in place. Findings revealed that the university made use of the SMS technology, which is by no means new in the academic world (Riordan and Traxler, 2005; Mbarika and Mbarika 2006), as it has been found to enhance communication between students and the university. The university is still exploring its benefits further. Also, faculty-student contact is regarded as a major part of the motivational factor for the students. This mechanism should be as solid as that of the contact mode since faculty members are concerned about lack of interaction with students (Fender 2001). This made the university introduced the contact sessions. Sadly, investigation revealed that the contact education students availed themselves more readily of this opportunity than did their distance education counterparts. A followup interview with the manager of the programme revealed that a recent research conducted by the Distance Education Unit of the faculty confirmed that there might be a strong correlation between attendance of students at contact sessions and their eventual performance. Distance education students' reluctance to attend the contact sessions probably resulted from the non-provision of accommodation during the contact session period. In addition, most distance education students lamented lack of contact with other students thereby they were forced to struggle alone. However, research on the impact of this is inconclusive (Kelsey and D'souza 2004).

Scholars have identified tutoring as an additional way of encouraging distance education students to finish their programs on time (Miller 2002; Moore and Kearsley 
2005). This would obviously depend on the nature of the course, the tutor and the student. Unfortunately the findings from the investigation revealed an absence of tutors (for both modes) for the six modules under investigation. It appeared that the service providers (i.e. the course presenters) employed by the Distance Education Unit seemed to be playing this role. However, the researchers thought this arrangement could not have been as effective since majority of them had contact with the students mainly during the contact sessions. Though module coordinators expressed doubts at locating suitable candidates to appoint to this position for each module, due to the experience required at this level, but the researchers are of the opinion that the faculty should establish a process of training to grow the required tutors (Moore and Kearsley 2005).

The last support mechanism to be mentioned here is the library facility provided by the university. According to the Association of College and Research Libraries (2004), it is the responsibility of universities to go the extra mile to meet the needs of distance education students. Though this study revealed that efforts at the university were extended to meet this need, nevertheless, one cannot overlook the fact that the conventional education students, along with certain of the distance education students that had access to libraries would be at an advantage over the others. A particular instance relevant to this study was the incapacity of students from distance education to access a library of law - a facility not located in the rural areas. To further complicate the issue, most of them also had no access to the Internet. The researchers are of the opinion that the time is right for the university to consider ways to diversify in this area.

\section{Students' performance as well as throughput and dropout rate data collected from the university administration}

Performances of students from the two delivery modes were much the same, and there were instances distance education students performed as well as their contact counterparts. This confirmed past research (Bernard 2004), the conclusion of which had mostly been 'No significant difference' (Russell 1999). Apart from the support structures of the university, another possible reason for this might be as a result of the diverse assessment forms adopted by the university. According to Mostert, Makola and Munondi (2004), these motivate distance education students, and prepare them for writing the summative assessment. However, assessment at a distance can be problematic (Clarke et al. 2004). The faculty could not make use of electronic assessment software, because most of the students had no access to the Internet (which could have been instrumental in combating the problem of late delivery and late feedback, and inconsistency already identified by the students as majority of the markers were contracted by the university. However, course presenters who participated in this study all wished they could be involved in the marking of the scripts, since this would place them in a position to identify the areas of weakness of their students. 
On the other hand, comparison of the dropout rates indicated that the dropout rate from the distance education was higher. Unfortunately, this situation has been used by many to determine the quality of a programme. Findings from this study indicated the following as possible reasons:

- Low level of preparation of students coming into a given study programme

- The problem of language proficiency

- Poor time management that results in surface learning

- Lack of motivation

- Ill-health (which is in line with the age brackets of distance learners, and HIV/ AIDS scourge and its related illnesses, which are rampant among educators in this country)

- Lack of funds

- The level of crime, and

- The status of distance learners in society (job promotion, new job responsibilities, pregnancy and family commitments)

In view of the above and in agreement with other scholars (Tucker 2001), it is our opinion that the low throughput rate of distance education students should not be taken out of context.

\section{CONCLUSION}

With the focus of this study on the three indices of assessment (access, delivery and output), some of the gaps identified in past comparative research have been highlighted and filled in. Firstly, this study does not suggest which mode is better, but African countries cannot flee from the fact that distance education is a tool to open up access to previously denied groups. The study reveals that it is time for African countries to start thinking about quality assurance (especially in relation to distance education) in terms of what would be relevant to their peculiar environments. This should include both instructional and non-instructional support structures. According to Fraser and Killen (2005), it is both immoral to knowingly admit students who for whatever reason have no chance of academic success, and to admit students, who have the potential to succeed but to treat them in ways that do not allow them to realise their potential.

\section{NOTES}

1. Conventional Education in the article refers to the 'ancient tutorial, in which a teacher ... talks to a group of learners, all together at the same time in the same place', (Moore and Kearsley 1996), while Distance Education refers to the form of study, which is not under the continuous, immediate supervision of tutors present with their students in 
lecture rooms or on the same premises, but which nevertheless benefit from the planning, guidance and tuition of tutorial organization (Holmberg 1993).

2. Quality in this study is defined as 'the conformance of an institution's goals, processes, input factors, and evaluation systems to the needs specified by their clients (the government, the students, the financiers and the employers of labour) in relation to what the institution too deems fit as relevant to the specified needs'.

\section{REFERENCES}

ACRL, see Association of College and Research Libraries.

Adekanmbi, G. 2004. The transformation of distance education in Africa. Available at: http:// www.col.org/forum/PCFpapers/Adekanmbi.pdf.

Aluko, R. 2007. A comparative study of distance education programmes assessed in terms of access, delivery and output at the University of Pretoria. Ph.D. thesis, University of Pretoria, Pretoria.

Association of College and Research Libraries. 2004. Distance learning library services. Available at: http://www.ala.org/ala/acrl/acrlstandards/guidelinesdistancelearning.htm.

Bates, A. 2005. Technology, E-learning and distance education. Second edition. USA: Routledge.

Bernard, R. et al. 2004. How does distance education compare with classroom instruction? A Meta-analysis of the empirical literature. Review of Educational Research 74 (3): 379-439.

Bloland, H. G. 1995. Postmodernism and higher education. Journal of Higher Education 66. Available at: http://owww.questia.com.innopac.up.ac.za/googleScholar. qst?doc1d=500165335.

Bornman, G. 2004. Programme review guidelines for quality assurance in higher education: a South African perspective. International Journal of Sustainability in Higher Education 5 (4): 372-383.

Braimoh, D. 2003. Transforming tertiary institutions for mass higher education through distance and open learning approaches in Africa: a telescopic view. South Africa Journal of Higher Education 17 (3): 13-25.

Bryman, A. 2004. Social research methods. Second edition. Britain: Oxford University Press.

Burke, T. 2002. The influence of distance learning on education. Available at: http://www. hernco.com/THBURKE/THE\%20OF\%DISTANCE...

Cele, N. and C. Brandt. 2005. Extending access and exclusive provision in distance higher education. Available at: http://www.col.org/pcf2/papers\%5Cele.pdf.

Chickering, A. and Z. Gamson. (Eds.). 1991. Applying the seven principles for good practice in undergraduate education. San Francisco: Jossey Bass Inc. Publishers.

Clarke, M., C. Butler, Schmidt-Hansen and M. Somerville. 2004. Quality assurance for distance learning: a case study at Brunel. British Journal of Educational Technology 35 (1): 5-11.

Cohen, L., L. Manion and K. Morrison. 2000. Research methods in education. Fifth edition. London: Routledge.

Council on Higher Education. 2004. Teaching and Learning: Chapter 5. Available at: url:file//A:ITEACHING\%20AND\%20LEARNING\%20CHAPTER\%205.htm. 
Department of Education. 2001. National Policy on Higher Education. South Africa: Pretoria.

—. 2004. Education statistics in South Africa at a glance in 2002. South Africa: Pretoria.

Dhanarajan, G. 2001. Distance education: promise, performance and potential. Open Learning 16 (1): 61-8.

Diaz, D. 2000. Carving a new path for distance education research. Available at: http:// ts.mivu.org.

Du Plessis, P. and W. van de Merwe. 2005. Mergers, different modes of delivery and assuring quality for learners. Available at: http://www.fotim.ac.za/fotim_conferences/papers/ duplessisandvdmerwe.doc.

Eaton, J. 2001. Distance learning: Academic challenges for higher education accreditation. CHEA: Monograph Series 2001 Number 1.

Fender, D. 2001. Student and faculty issues in distance education. Available at: www.mtsu. edu/ itconf/proceed01/4.pdf.

Fraser, W. and R. Killen. 2005. The perceptions of students and lecturers of some factors influencing academic performance at two South African universities. Perspectives in Education 23 (1): 25-40.

Fraser, W. and E. Lombard. 2002. Prominent paradigms of performance and the dilemma of distance education to deliver. Perspectives in Education 20 (3): 85-102.

Gamede, T. 2005. The biography of 'access' as an expression of human right in South African Education policies. Ph.D. thesis. Pretoria: University of Pretoria.

Garrison, D. and W. Archer. 2000. A transactional perspective on teaching and learning: $a$ framework for adult and higher education. Oxford: Pergamon.

Gelderbloem, N. 1996. The role of the university in post-apartheid South Africa. M.Phil. mini-thesis. Western Cape: University of Western Cape.

Goold, A. and R. Rimmer. 2000. Factors affecting performance in first year computing. SIGCSE Bulletin 32 (2): 39-43.

Hardy, M. and A. Bryman. 2004. Handbook of data analysis. Thousand Oaks: Sage Publication.

Hellman, J. 2003. Distance education: its advantages and shortcomings. In UN Chronicle (online edition). Available at: http://www.un.org/Pubs/chronicle/2003/issue4/0403p47. asp.

Herman, L. and A. Mandell. 1999. On access: towards opening the life-world within adult higher education in the UK. In The convergence of distance and conventional education, eds. A. Tait and R. Mills. London: Routledge.

Holmberg, B. 1993. Key issues in distance education: an academic viewpoint. In Distance education: new perspectives, eds. K. Harry, M. John and D. Keegan. London: Routledge.

- 2001. Distance education in essence. Oldenburg: Bibliotheks.

Jansen, J. 2001. Access and values: Values, education and democracy in the $21^{\text {st }}$ Century. Invited Paper Presentation.

Kelsey, K. and A. D'souza. 2004. Student motivation for learning at a distance: Does interaction matter? Online Journal of Distance Learning Administration. Available at: http://www.wetsga.edu/\%7Edistance/ojdla/summer72/kelsey72.html.

Lambert, S. and R. Williams. 1999. A model for selecting educational technologies to improve student learning. HERDSA Annual International Conference: Melbourne, 12-15 July. 
Logan, K. and P. Thomas. 2002. Learning styles in distance education students learning program. Available at: www.ppig.org.

Lelliot, A., S. Pendlebury and P. Enslin. 2000. Online education in Africa: promises and pitfalls. Available at: file://H: $\backslash$ Promises and pitfalls_files $\backslash$ Lelliot.htm.

Lockee, B., M. Moore and J. Burton, J. 2001. Old concerns with new distance education. Available at: www.educause.edu/ir/library/pdf/EQMO120.pdf.

Makin, V. 2001. Trends and needs in distance education research: The death of distance. Progressio 23 (2): 200.

Mbarika, V. and I. Mbarika. 2006. Burgeoning wireless networks connect Africans to the world and each other. Available at: http://www.spectrum.ieee.org/may06/3426.

McKenzie, K. and R. Schweitzer. 2001. Who succeeds at university? Factors preceding academic performance in first year Australian university students. Higher Education and Development 20 (1): 21-33.

Miller, S. 2002. A utilization-focused evaluation of on-line tutoring for a New Jersey Community College. D. dissertation, Pepperdine University, Malibu.

Moore, M. and G. Kearsley. 1996. Distance education: A systems view. Belmont: Wadsworth.

- 2005. Distance education: a systems view. Belmont, CA: Wadsworth.

Morley, L., E. Unterhalter and A. Gold. 2003. Enterprise culture, equity and gendered change in Commonwealth higher education. In The enterprising quality: Reform, excellence and equity, ed. G. Williams. Buckingham: Open University Press.

Morrow, W. 1993/4. Entitlement and achievement in education. Studies in Philosophy and Education 13 (1): 33-37.

Mostert, J., M. Makola and J. Munondi. 2004. Integrated curriculum design. Paper delivered at the RDF planning workshop of UNISA in Johannesburg.

Mostert, J. 2006. The challenges for an African distance education learner - a distance educator's perspective. South African Journal of Higher Education 20 (3): 137-149.

Pityana, N. 2006. Higher education and the challenge of skills development: a contribution to JIPSA. Address delivered at the official launch of the Joint Initiative for Priority Skills Acquisition (JIPSA). 27 March.

Qurashi, E, L. Morton and E. Antosz. 2002. An interesting profile - university students who take distance education courses show weaker motivation than on-campus students. Online Journal of Distance Learning Administration V(IV). Available at: http://www. westga.edu/\%7Edistance/ojdla/winter54/Quershi54.htm.

Ragan, L. 1999. Good teaching is good teaching: An emerging set of guiding principles and practices for the design and the development of distance education. Available at: http:// www.educause.edu/ir/library/htm/cem9915.html.

Raphael, A. 2006. A needs assessment: a study of perceived need for student services by distance learners. Online Journal of Distance Learning Administration IX(II): Summer. Available at: http://www.westga.edu/ distance/ojdla/summer41/raphael41.htm.

Riordan, B. and J. Traxler. 2005. The use of targeted bulk SMS texting to enhance student support, inclusion and retention. Proceedings of the IEEE International Workshop on Wireless and Mobile Technologies in Education (WMTE'05).

Rockwell, K., J. Furgason and D. Marx. 2000. Research and evaluation needs for distance education: A Delphi study. Available at: http://www.westga.edu/ distance/ojdla/fall33/ rockwell33.html. 
Russell, T. 1999. The no significance difference phenomenon: A comparative research annotated bibliography on technology for distance education. North Carolina State University: Office of instructional Telecommunications.

Sahney, S., D. Banwet and S. Karunes. 2004. Conceptualizing total quality management in higher education. The TQM Magazine 16 (2): 145-159.

Scott, I. 2003. Balancing excellence, equity and enterprise in a less-industrialized country: The case of South Africa. In The enterprising quality: Reform, excellence and equity, ed. G. Williams. Buckingham: Open University Press.

Singh, M. 2000. The HEQC and the challenges of quality assurance in South African higher education. Paper presented at the Conference on Quality Assurance and Distance Learning, 29 January to 3 February 2000. UNISA, Pretoria.

South Africa Information. 2007. Budget: lion's share for education. Available at: http://www. southafrica.info/ess_info/sa_glance/education/update/budget007-educati.

Smith, A. and F. Webster. 1997. Changing ideas of the university. In The Postmodern university? Contested visions of higher education in society, eds. A. Smith and F. Webster. Buckingham: Open University Press.

Telford, R. and R. Masson. 2005. The congruence of quality values in higher education. Quality Assurance in Education 13 (2): 107-119.

Tsolakidis, C. 2000. Distance education: A second best in learning? Available at: http://toide. anadolu.edu.

Tucker, S. 2001. Distance education: Better, worse, or as good as traditional education? Online Journal of Distance Learning Administration, IV (IV), Winter. Available at: http://www.westga.edu/ distance/ojdla/winter44/tucker44.html.

Umar, A. 2006. Quality assurance procedures in teacher education: the case of the National Teachers' Institute, Kaduna, Nigeria. In Perspectives in distance education: Towards a culture of quality, eds. B. N. Koul and A. Kanwar. Vancouver: Commonwealth of Learning.

USA Funds. 2007. Access to education - financial barriers still bar the door to higher learning for some students. Available at: http://www.usafunds/higher_ed_access/financial_ burdens.htm.

Welch, A. (Ed.). 2000. Third world education: quality and equality. New York: Garland Publishing.

Green, D. (Ed.). 1994. What is quality in higher education? Buckingham: Open University Press.

Yorke, M. 1999. Leaving early: Undergraduate non-completion in higher education. UK: Falmer Press. 